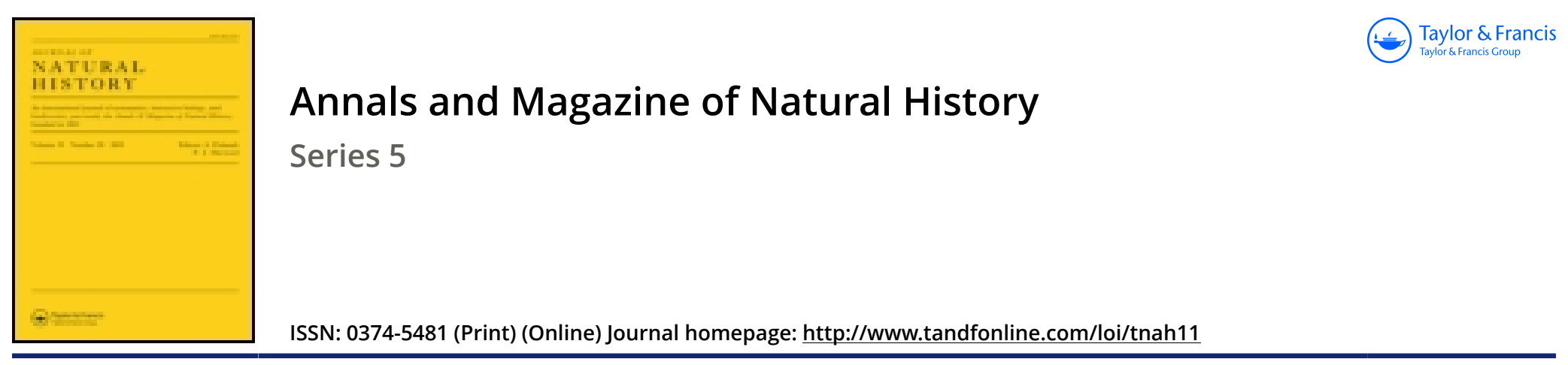

\title{
VII.-Diagnosis of a new species of Hesperomys from North America
}

\section{Oldfield Thomas}

To cite this article: Oldfield Thomas (1887) VII.-Diagnosis of a new species of Hesperomys from North America, Annals and Magazine of Natural History, 19:109, 66-66, DOI: $10.1080 / 00222938709460200$

To link to this article: http://dx.doi.org/10.1080/00222938709460200

曲 Published online: 12 Oct 2009.

Submit your article to this journal $₫$

Џll Article views: 1

Q View related articles 두 
with the base, costal margin, the upper part of the cell, and the exterior margin broadly dark brown. Posterior wings with the base, the costal, exterior, and inner margins, two spots near the anal angle, and an interrupted submarginal line dark brown.

Underside. Both wings greyish brown, lighter in the middle, with the orange-colour showing through, crossed with several bands of white and two white submarginal lines Posterior wings with two spots near the anal angle, both irrorated with silver, the spot furthest from the angle bordered on three sides with orange.

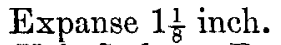

Hab. Delagoa Bay (Mrs. Monteiro).

In the collection of $\mathrm{H}$. Grose Smith.

\section{VII.-Diagnosis of a new Species of Hesperomys from North America. By Oldfield Thomas. \\ Hesperomys (Vesperimus) Taylori, sp. n.}

Allied and very similar in colour to $H$. michiganensis, Aud. $\&$ Bachm., but not more than about half the bulk of that species. Centre of back not darker than sides; tail indistinctly bicolor; foot-pads black, five on the fore and six on the hind feet; soles naked nearly to the heel.

Measurements of an adult male (in skin):-Head and body (c.) 53 millim.; tail 32 ; hind foot, without claws, 13; ear, above crown, 5.0 ; skull, basal length 150 , greatest breadth 9.5 ; nasals, length 6.5 ; interorbital constriction 3.4 ; interparietal, length $2 \cdot 0$, breadth 5.0 ; palate, length $8 \cdot 4$; palatal foramen $3 \cdot 6$; length of molar series $2 \cdot 7$; basicranial axis $5 \cdot 6$.

Hab. San Diego, South 'Texas (W. Taylor).

The smallest hitherto-known North-American Hesperomys, and the only near ally of $H$. Taylori, is $H$. michiganensis, which has a hind foot ranging in length from 17 to 19 millim. and a skull 20 millim. in basal length.

It is with much pleasure that I connect with this interesting and diminutive animal, the smallest of its genus, the name of its discoverer, Mr. William Taylor, to whom the NaturalHistory Museum is indebted for many rare Rodents. 